Ethiopian Journal of Environmental Studies \& Management 8(Suppl. 2): 976 - 982, 2015.

ISSN:1998-0507

Submitted: August 13, 2015

doi: http://dx.doi.org/10.4314/ejesm.v8i2.11S

\title{
EFFECT OF WASTE DUMPSITES ON PROXIMATE RESIDENTIAL PROPERTY VALUES IN IBADAN, OYO STATE, NIGERIA
}

*NWOSU, A.E. ${ }^{1}$ AND OLOFA, S.A. ${ }^{2}$

${ }^{1}$ Department of Estate Management, Federal University of Technology, Akure,

P.M.B. 704 Akure, Ondo State, Nigeria

${ }^{2}$ Department of Estate Management, The Polytechnic Ibadan, PMB 22, Ibadan, Nigeria

\begin{abstract}
The study examined the effect of waste dumpsite on proximate property values in Apete, Ibadan. Residents of randomly selected 100 residential properties located around a waste dumpsite in the study area were administered structured questionnaires to elicit information for the study. Questionnaires were administered to determine the effect of the proximity of waste dumpsite on the rent paid on their residential apartments. The data collected were analyzed using multiple regressions. The result of the analysis shows that, distance of residential property from waste dumpsite is not significant with a p-value of 0.889 . Hence, we conclude that waste dumpsite does not have significant effect on residential property value. However, since the $p$-value for $X i, X 2$, and $X 3$ are less than 0.05 , it is concluded that income level, building type and demand for building have significant effect on residential property values. This can be attributed to the fact that majority of the occupiers are students and low income earners. Furthermore, most of the building types are tenement, which are of very high demand by the students in the study area. The study recommends that the investors should come and invest in properties since waste dumpsite does not affect the value of properties in the area.
\end{abstract}

Key Words: Waste, Dumpsite, Proximity, Property values

\section{Introduction}

Nigeria is rapidly moving towards industrialization. Before the oil boom, economic growth was slow but with an increase in foreign exchange from the oil sector and the introduction of second tier foreign exchange market, individuals as well as government were able to finance development programs which place Nigeria on the way to industrial revolution, and industrial revolution go hand in hand with production and its associated waste generation (George, 2000). The quantity and generation rate of wastes in Nigerian cities have increased at an alarming rate over the years with lack of efficient and modern technology for the management of the wastes (Babayemi and Dada, 2009). Waste is anything that is no longer of use to the disposer. It can also be defined as any unavoidable material resulting from an activity, which has no immediate economic demand and which must be disposed of (NISP, 2003). Waste is commonly classified into three. These are liquid, gaseous and solid wastes. Liquid wastes are waste dissolved in water emanating from industrial processes known as 
effluent, domestic liquid, acid waste and waste oil from workshop (NISP, 2003).Solid wastes could be defined as non-liquid and nongaseous products of human activities, regarded as being useless. It could take the forms of refuse, garbage and sludge (Lenton and Omotosho, 2004).

In most urban centers in Nigeria, wastes are disposed of by dumping in open areas, which produces health and pollution problems by encouraging the growth of organisms that can transmit diseases to people living around that vicinity (Freeman, 1979). Recent experience has shown that both the government approved and illegal dumpsites are being poorly managed thereby becoming ready sources of pollution with a great consequence on human health and properties (Adewusi and Onifade, 2006). It must be noted that the ever increasing volume of waste has overwhelmed the urban administrators' capacity. Cities in Nigeria, being among the fast growing cities in the world are faced with the problem of solid waste generation (Onibokun and Kumuyi, 1996). The implication is serious when a country is growing rapidly and the wastes are not efficiently managed. Waste generation scenario in Nigeria has been of great concern both locally and globally, and of the different categories of wastes generated, solid wastes had posed a hydraheaded problem beyond the scope of various solid waste management systems in Nigeria as the streets experience continual presence of solid waste from commercial activities (Geoffrey, 2005). The effect of uncontrolled solid waste, as environmental contaminants, is not limited to human life but its effect is significantly observed on property value and life span. According to Simon (2002), properties affected by environmental contamination (refuse dumps) are expected to sell for a discount price compared with clean and comparable properties in neater environment. The generation rate, collection and disposal of solid wastes are functions of several factors which if well considered and appropriated could bring the desired solution to the waste management problems in Nigeria. However, the reverse in some cases affect the real estate development and investment. A push effect like the presence of waste dumpsite may affect property value and the satisfaction the occupants derive from the environment and the property they occupy (Jackson, 2001). Bello and Bello (2005) affirmed that the presence of solid wastes normally affect the value of a property. It must be understood that environmental contamination resulting from solid wastes can affect the full spectrum of property types in an area.

Various researchers have undertaken to study dumpsites location, solid waste generation pattern, residents' satisfaction in Nigeria but there appear to be no agreement on their views on the effect on property values. Many factors interplay to create property values (Bello and Bello, 2006, Udo and Egbenta, 2007). This could be economic, institutional or environmental. Factors that negatively affect the value of real property injure ownership motives and goals. They also damage the investor's interest and discourage subsequent investment. Bouvier et al. (2002) studied the effect of landfills on rural residential property values. The study examines six landfills, which differ in size, operating status, and history of contamination. The effect of each landfill is estimated by the use of multiple regressions. In five of the landfills, no statistically significant evidence of an effect was found. In the remaining case, evidence of an effect was found, indicating 
that houses in close proximity to this landfill suffered an average loss ofabout six percent in value.Bello (2005) using empirical evidence from refuse dumps located at Oke-Afa (Isolo), AbuleEgba and Ojudu in Lagos metropolis discovered that rental values of the properties adjoining the dumpsites have reduce rent as much as $37 \%$ in Oke- Afa for blocks of flats and $33 \%$ in Ojudu for tenement building. Ukabam (2005) examined the impact of waste dumpsite on housing prices. The comparison method, mean, correlation and factor analysis were adopted in determining the impact of Olusosun and Solus dumpsites on residential property values on Howson wright and Johnkay Estates, the study confirms the negative externalities of waste dumpsite on housing prices.

Ogedengbe and Oyedele (2006) examine the effect of waste on property values in a Nigerian city (Ibadan). The data collected were analyzed using chi-square, frequency distribution, mean and percentages. The results show that the waste dumps have significant negative impact on the values of the properties in the area Adewusi and Onifade (2006) examine the effects of urban solid wastes on physical environment and property transactions in Surulere local government area of Lagos State. The data collected were analyzed using descriptive statistics, the result shows that rents paid on properties located far away from dumpsites and property transaction rate became very slow and unattractive as one approaches a dumpsite. Bello and Bello (2008) conducted a research on the willingness to pay for environmental amenities in Akure Nigeria. The study included environmental amenities such as waste water disposal, water and electricity supplies, neighbourhood roads and other locational services. The study used a two-staged hedonic model to examine the willingness to pay for better environmental services by residents of two neighbourhoods in Akure, Nigeria. He combined multiple regressions and predictive model to determine property values as a function of housing attributes and logistic model as willingness to pay. The study identified households' income, distance away from the refuse dump site and regularity of electricity supply as the major factors that influenced household's willingness to pay for better environmental services.

Bello (2009) carried out a study on the effects of waste dump sites on proximate property values in Lagos, Nigeria using three dump sites located at Olusosun, Abule Egba and Solous adopting $1 \mathrm{~km}$ distance measurement to assess the effects of the dumpsite on the neighbourhoods. The research sampled 334 residents from the three waste dump sites and 107 Estate Surveying and Valuation firms in metropolitan Lagos. The study was in the main to measure the effect of waste dump on property values and to develop an appropriate valuation methodology to carry out valuation of properties affected by waste dump sites. A combination of valuation methodologies was adopted such as Paired Sales Analysis, Contingent Valuation Analysis, Option Pricing Model and Hedonic Approach. The study found that there was a weak linear relationship between rental value and satisfaction of occupants in the neighbourhood of the waste dumps.

Ukabam (2005) established that residents of properties in close proximity to waste dumpsites in Lagos metropolis suffer existence of dis-amenities, the effect of which include void and lower rental values. This carries with it an indirect implication of reduction in property tax, longer period to recoup capital invested, repayment of mortgage and overall 
reduction in the country's gross domestic product (GDP). Results from most of previous studies generally support the notion that waste dumpsites have negative effects on property values. Specifically property values decreases with closeness to the dumpsites. However, Udo and Egbenta (2002) examined the effects of domestic waste dumpsites on rental values of residential properties in Enugu, Nigeria. The study differed from the foregoing popular belief that waste dumpsite affect property values negatively. Other factors could be harnessed to boost rental values of properties in our cities. Akinjare et al. (2011) studied the prediction of residential property values around landfill neighborhoods in Lagos, Nigeria. This study establishes a predictive model for residential property values within $1,200 \mathrm{~m}$ proximity to the four landfills in Lagos State by examining their varying sizes, operating status and history inclusive of diminution tendencies. The relationship between each landfill and property values were measured based on interval of 300meters up to 1, 200 meters in concentric rings. The resultant model validates the findings of the study that across the four landfill sites, increases in property values were evident as distance away from the landfills increased indicating that residential houses in close proximity to the landfills suffered value loss. Property appreciation relative to distance averaged $5.75 \%$ within the concentric rings for all four landfills. The study suggested the closure of all landfills within residential areas and a relocation of such to uninhabited areas in the city's outskirt in order to promote sustained value appreciation. Ijasan et al. (2012) studied depressionary effect of proximate of residential properties to waste dump site in Nigeria using Solous land fill as a case study. This study takes a special focus on the resident's perspective based on the linear proximity to waste disposal sites. 260 questionnaires were distributed to residents within $1 \mathrm{~km}$ to the site and Estate Surveyors in the area. The correlation between respondent's profile and opinions are analyzed and it revealed that the site has major impacts on the residents perceived quality of life, security and total outlook of the area. It also showed that there is a negative correlation between the distance from landfill and the perceived quality of life of residents. Mmom and Mbee (2013), examine the impact of landfill on real estate values in Port Harcourt metropolis. 2000 real estate within 500 metres radius from landfill sites were identified and about 600 property owners/agents representing 30 percent of the entire real estate owners were sampled for study. The study thus observed that there is low pricing of property contiguous to landfill, in most cases; people are less willing to live or acquire properties near landfill locations. Similarly, occupants are unwilling to rent houses near landfill sites thereby demeaning the value of such real estate.

This research tends to examine the effects of waste dumpsites on proximate residential values in Ibadan. It is in the light of this that this study is undertaken to establish the nature of the effect waste dumpsites has on proximate property values with particular focus on the environs of Awotan dumpsite, Apete, Ibadan.

\section{Research Methodology}

Awotan dumpsite along Apete-Akufo read, Apete, Ido Local Government Area, Ibadan- one of the approved dumpsites was chosen as the study area. The Oyo State Government established the dumpsite in the year 2000, and has since then been intensively used. The target populations 
are the residents of properties within 300 meter radius to the location of the dumpsites. This is to preclude the possibility of information that may be gathered from an excess radius farther away from 300 metres radius from skewing the result. A total of 100 residential properties within the axis of the waste dumpsite in the study area were purposively selected using stratified random sampling techniques which affords the opportunity of picking every third house in the study area within the radius. The data collected were analyzed using multiple regressions.

\section{Testing of Hypotheses}

$\mathrm{H}_{\mathrm{O}}$ : Waste dump site has no significant effect on proximate residential property values in the study area.

The p-value approach was adopted and the decision rule is as follows:

Decision rule: Reject Ho if $\mathrm{p}$-value is less than the level of significance $(x=0.05)$, otherwise do not reject.

Operationalisation of Variables

\begin{tabular}{|l|l|l|}
\hline Variables & Description of Variables & \multicolumn{2}{l|}{ Measurement } \\
\hline Dependent & Rental Values & Actual ( $)$ \\
\hline$Y$ & \multicolumn{2}{|l|}{} \\
\hline Independent Variables & Actual ( $)$ \\
\hline$X_{1}$ & Income level of respondent & tenement, Self-contained, Flats, \\
\hline$X_{2}$ & Building type of respondent & Actual number \\
\hline$X_{3}$ & Demand & Yes (1) Otherwise (0) \\
\hline$X_{4}$ & Accessibility to place of work & Kilometers \\
\hline$X_{5}$ & Distance from waste dumpsite &
\end{tabular}

Therefore the regression model is given as $Y=\beta_{0}+\beta_{1} X_{1}+\beta_{2} X_{2}+\beta_{3} X_{3}+\beta_{4} X_{4}+\beta_{5} X_{5}$

Test of significance was performed for each of the regression coefficients $\beta_{\mathrm{i}}$ to $\beta_{5}$ to determine the extent to which the variable $\left(\mathrm{x}_{\mathrm{i}}\right)$ affects rental values of proximate properties to waste dumpsites. To examine the strength or predictive power of the model, $\mathrm{R}$ square (adjusted) was computed. Generally, the closer the $\mathrm{R}^{2}$ (adj.) is to 1 , the better is the model.

\section{Results and Discussion}

Table 1: Model Summary

\begin{tabular}{|l|l|l|l|l|}
\hline Model & R & R Square & Adjusted R Square & Std. Error of the Estimate \\
\hline 1 & $.973(\mathrm{a})$ & .947 & .942 & 730.28466 \\
\hline
\end{tabular}

Table I examines the strength of the predictive power of the model, R square (adjusted). With an $\mathrm{R}^{2}$ of 0.947 , this implies that the prediction explains about $95 \%$ of the rental values which is very significant.

Table 2: Significance of Factors on Rental Values

\begin{tabular}{|l|l|l|l|l|l|}
\hline Model & Sum of Squares & D.F & Mean Square & F & Sig \\
\hline Regression & 789026666.394 & 7 & 112718095.199 & 211.353 & .000 \\
Residual & 44265201.738 & 83 & 533315.684 & & \\
Total & 833291868.132 & 90 & & & \\
\hline
\end{tabular}

Predictors: (Constant) $\mathrm{x}_{1}, \mathrm{x}_{2}, \mathrm{x}_{3}, \mathrm{x}_{4}, \mathrm{x}_{5}$

Dependent Variable: Rental value 
Table 2 shows that the $P$ value (.000) is less than the level of significance $(\alpha=0.05)$. This implies that some or all the perceived factors are significant, therefore it is good to predict rental values subject to the above mentioned factors.

Table 3: Test of Significance for Factors on Rental Values

\begin{tabular}{|l|l|l|l|}
\hline Model & Unstandardized Coefficient & $\mathrm{T}$ & $\mathrm{Sig}$ \\
\hline Constant & 8093.792 & 2.546 & .013 \\
Income level..... $\mathrm{x}_{1}$ & 839.953 & 2.955 & $.004^{* *}$ \\
Building Type....... & 1495.510 & 3.258 & $.002^{* *}$ \\
Demand........... & -4.840 & $.000^{* *}$ \\
Accessibility......... & -1753.958 & -.951 & .344 \\
$\begin{array}{l}\text { Distance of property from waste } \\
\text { dumpsite ............. }\end{array}$ & -818.628 & -.141 & .889 \\
\hline
\end{tabular}

0.05 denote significant level

Table 3 shows the result of test of significance performed for the factors. The regression model is given as:

$\mathrm{Y}=8093.792+839.953 \mathrm{x}_{1}+1495.51 \mathrm{x}_{2}-$ $1753.958 \mathrm{x}_{3}-818.628 \mathrm{x}_{4}-104.297 \mathrm{x}_{5}$

From the result of the analysis, distance of residential property from waste dumpsite is not significant with a p-value of 0.889 . Hence, we conclude that waste dumpsite does not have significant effect on residential property value. However, since the $\mathrm{p}$-value for $\mathrm{Xi}, \mathrm{X} 2$, and $\mathrm{X} 3$ are less than 0.05 , it is concluded that income level, building type and demand for building have significant effect on residential property values. This can be attributed to the fact that majority of the occupiers are students and low income earners. Furthermore, most of the building types are tenement, which are of very high demand by the students in the study area. These findings is at variance with the findings of Bello and Bello (2005), Ogedengbe and Oyedele (2006), and Adewusi and Onifade (2006), which assert that waste dumpsites have negative effect on rental values. The reason for the nonconformity is traceable to the fact that the study area is in close proximity to the Polytechnic of Ibadan, which resulted in the high rate of demand for residential properties by the students who are unable to secure accommodation within the school premises. Thus this study is in conformity with the findings of Udo and Egbenta (2002) that waste dumpsite does not affect property values negatively.

\section{Recommendation and Conclusion}

In conclusion, the results show that demand, building type and income level are the determining factors for rental value in the study area. Hence, waste dumpsite does not have any negative effect on the rental value in the area contrary to the assertion of many researchers. Although, it was observed that the area is dominantly occupied by low income class and students because of the building type that is mainly seen in the area and the close proximate of a tertiary institution (The Polytechnic Ibadan). The study recommends that the investors should come and invest in properties since waste dumpsite does not affect the value of properties in the area.

\section{References}

Adewusi, A.O. and Onifade, F.A. (2006). "The Effects of Urban Solid Wastes on Physical Environment and Property Transaction in Surulere Local Government Area of Lagos State". Journal of Land Use and Development Studies, 2(1): 71-78. 
Akinjare, O.A., Oloyede, S.A., Ayendu, C.A. and Ajibola, M.A. (2011). "Predicting Residential Property Values around Landfill Neighbourhood in Lagos Nigeria" Mediterranean Journal of Social Sciences, 2(2): 211-222.

Babayemi, J.O. and Dauda, K.T. (2009). "Evaluation of Solid Waste Generation, Categories and Disposal Option in Developing Countries, A Case Study of Nigeria". Journal of Applied Science and Environmental Management, 13(3): 83-88.

Bello, M.O. and Bello, V.A. (2005). "The Valuation of Environmental Contaminated Properties" The Position of the Nigerian Institution of Estate Surveyors and Valuer"s. Journal of Land Use and Development Studies, 1(1): 52 - 59.

Bello, M.O. and Bello, V.A. (2006). Sustainable Investment in the Nigeria Housing Sector: What Went Wrong? In Okewole, I.A. (et al) (eds) The Built Environment: Innovation Policy and Sustainable Development. Convenant University, Ota: 356-364.

Bouvier, R.A., Halstead, J.M., Conway, K.S. and Manato, A.B. (2000). "The Effect of Landfill on Rural Residential Property Values. Some Empirical Evidence". The Journal of Regional Analysis and Policy, 30(2): 23-34.

Freeman 111, A.M. (1979). The Benefit of Environment Improvement. Baltimore: Resources for the Future. John Hopkins Press.

Geoffrey, I.N. (2005). The Urban Informal Sector in Nigeria: Towards Economic Development, Environment Health and Social Harmony. Global Urban Development Magazine1(1)

Ijasan, K.C., Oloke, O.C., Adeyemo, O.A and Gbadamosi, A.F. (2012). "Depressionary Effect of Proximaty of residential Properties to Waste disposal sites in Nigeria." Ethiopian Journal of Environmental Studies and Management. 5(4): 574-584.

Jackson, T.O (2001). "Environmental Risk Perception of Commercial and Industrial Real Estate Lenders".Journal of Real Estate Research, 22(3) 272277.

Lenton, T.G. and Omotosho, O. (2004). "Landfill operations in the Niger Delta Region of Nigeria". Journal of Engineering Geology, 73(1-2): 171177.

Mmom, P.C. and Mbee, M.D. (2013). "Impact of Landfill Site on real Estate Values in Port Harcourt Metroplois, Nigeria”. Journal of Humanities and Social Sciences, 10(6): 34-39.

Ogedengbe, P.S. and Oyedele, J.B. (2006). "Effect of Waste Management on property Values in Ibadan Nigeria". Journal of Land Use and Development Studies, 2(1): 71-78.

Onibokun, A.G. and Kumuyi, A.J. (1996). Urban Poverty in Nigeria: Towards Sustainable Strategies for its Alleviation Centre for African Settlement Studies and Development, Ibadan Nigeria. CASSAD Monograph Series (10): 1-2.

Simon, R.A. (2002). Estimating Proximate property Damage from PCB Contamination in a Rural Market. A Multiple Technique Approach.The Appraisal Journal October.

Udo, G.O. and Egbenta, I.R. (2007). "Effects of Domestic Waste on Rental values of Residential Properties in Enugu. Nigeria". Journal of Development Studies, 6(1): 80 -89.

Ukabam, T.A. (2005). "Impact of Dumpsite on Housing Prices in Lagos Metropolis". Journal of Environmental Issues (Jenvscs), 1(1): 37 - 49. 